\title{
Kajian Valuasi Ekonomi Ekosistem Hutan Mangrove Di Desa Kaliwlingi Dan Desa Sawojajar, Kabupaten Brebes, Jawa Tengah
}

\author{
Yonanda Alodea Christy*, Wilis Ari Setyati, Rudhi Pribadi \\ Departemen IImu Kelautan, Fakultas Perikanan dan IImu Kelautan, Universitas Diponegoro \\ JI. Prof.H.Soedarto S.H, Tembalang,Semarang, Jawa Tengah 50275 Indonesia \\ *Corresponding author, e-mail : deachristy2426@gmail.com
}

\begin{abstract}
ABSTRAK : Ekosistem hutan mangrove merupakan ekosistem yang berada di kawasan pesisir yang memiliki fungsi fisik, fungsi ekologi dan fungsi ekonomi. Dampak kerusakan ekosistem hutan mangrove dapat dipulihkan dengan adanya kegiatan rehabilitasi dan konservasi di kawasan hutan mangrove. Pemanfaatan nilai ekonomi dari ekosistem hutan mangrove memerlukan perhitungan valuasi ekonomi guna melihat aktivitas ekonomi yang ada pada ekosistem hutan mangrove. Tujuan penelitian ini yaitu untuk menghitung nilai total ekonomi di ekosistem hutan mangrove dan merekomendasikan strategi pengembangan dan pengelolaan kawasan ekosistem mangrove di Desa Kaliwlingi dan Desa Sawojajar, Kabupaten Brebes, Jawa Tengah. Metode penelitian yang digunakan adalah metode deskriptif dan eksploratif. Penentuan lokasi penelitian dilakukan dengan metode purposive sampling. Sampel penelitian yang diambil adalah masyarakat yang mempunyai mata pencaharian berkaitan dengan keberadaan ekosistem hutan mangrove secara langsung dan tidak langsung. Berdasarkan hasil penelitian menunjukan nilai total ekonomi ekosistem hutan mangrove di Desa Kaliwlingi adalah sebesar Rp 12.912.098.100 yang didapatkan dari total use value sebesar $\mathrm{Rp}$ 9.927.638.100 dan total non use value sebesar Rp 2.984.460.000. Nilai total ekonomi di Desa Sawojajar adalah sebesar Rp 5.519.784.145 dengan jumlah nilai use value sebesar Rp 3.670.377.145 dan nilai non use value sebesar Rp 1.849.407.000.
\end{abstract}

Kata kunci : ekosistem; mangrove; valuasi ekonomi; rehabilitasi; nilai total

\section{Mangrove Forest Ecosystem Economic Valuation Study in Kaliwlingi Village and Sawojajar Village, Brebes Regency, Central Java}

\begin{abstract}
Mangrove forest ecosystem are the ecosystem that is located in coastal environment that have a physical function, ecological function and economic function. The effect of damaged can be heal if there is a rehabilitation and conservation in mangrove ecosystem. The value of economic from mangrove ecosystem needs a calculation of valuation to look up the economic activity in mangrove forest ecocsystem. The aim of the research are calculate the economic total value of mangrove forest ecosystem and recommend a developing and managing strategy of mangrove ecosystem at Kaliwlingi Village and Sawojajar village. The method of the research is use descriptive and explorative method. The location of the research conducted by purposive sampling method. The sample of the study is the residents related to the existence of the mangrove ecosystem directly and indirectly. Based on the results of the research showed the total economic of mangrove forest ecosystem in Kaliwlingi Village is Rp 12.912.098.100 that comes from the total amount of use value $R p$ 9.927.638.100 and non use value $R p$ 2.984.460.000. The total economic value in Sawojajar village is Rp 5.519.784.145 that comes from the total amount of use value $R p$ 3.670.377.145 and non use value $R p$ 1.849.407.000.
\end{abstract}

Keywords: Ecosystem; Mangrove; Economic Valuation; Rehabilitation; Economic Value

\section{PENDAHULUAN}

Keanekaragaman hayati laut di Indonesia yang beragam sangat erat kaitannya dengan kelimpahan sumberdaya alam. Sumberdaya alam merupakan aset penting suatu negara dalam 
melaksanakan pembangunan, khususnya pembangunan pada sektor ekonomi. Kelimpahan sumberdaya alam tidak hanya mempunyai peran untuk memenuhi kebutuhan hidup manusia, namun juga dapat berkontribusi cukup besar bagi kesejahteraan suatu bangsa (the wealth of nation) (Prasetiyo et al., 2015). Pemanfaatan dan pengelolaan sumberdaya alam harus dilakukan secara optimal, lestari dan berbasis lingkungan agar sumberdaya alam tersebut dapat berkelanjutan dan berguna di masa mendatang.

Sumberdaya alam melimpah di Indonesia salah satunya ialah adanya ekosistem hutan mangrove yang merupakan salah satu sumberdaya yang memiliki fungsi dan peran penting dalam satuan ekosistem. Ekosistem hutan mangrove berdampak pada kegiatan ekologi diantaranya sebagai tempat mencari makan (feeding ground), tempat pemijahan (spawing ground) dan tempat pemeliharaan (nursery ground) bagi ikan maupun biota yang tinggal disekitar hutan mangrove.

Hutan mangrove merupakan sumber daya khas pesisir yang menyediakan dan berpotensi untuk menghasilkan berbagai produk dan layanan jasa lingkungan yang menunjang kebutuhan hidup masyarakat pesisir dalam berbagai aktivitas ekonomi. Perlindungan dan pelestarian ekosistem alam hutan mangrove sangat penting dilakukan agar tidak terjadi eksploitasi hutan mangrove sehingga fungsi utamanya menjadi hilang (Putra, 2016). Pemanfaatan hutan mangrove di Indonesia sering mengalami penurunan akibat dari masyarakat yang menilai hutan mangrove hanya dari segi ekonominya saja, tanpa memperhitungkan manfaat fisik dan ekologi dari hutan mangrove (Ariftia et al., 2014).

Ekosistem mangrove memberikan manfaat langsung maupun tidak langsung bagi kehidupan manusia. Manfaat ekosistem mangrove sering digunakan manusia dengan cara yang tidak bijaksana dengan melakukan kegiatan secara destruktif, hal ini dibuktikan dengan adanya degradasi perubahan luasan ekosistem mangrove. Menurut Suyono et al. (2015), luas hutan mangrove yang semakin berkurang, sering terjadi seiring dengan pesatnya kebutuhan masyarakat, serta meningkatnya pembangunan dikawasan pesisir salah satunya Pantai Utara Jawa (Pantura). Luasan ekosistem mangrove diperparah dengan keberadaan ancaman lain dari manusia seperti limbah pabrik, sampah dan reklamasi.

Ekosistem hutan mangrove lebih baik dikelola secara konservatif dengan melestarikan dan melindungi ekosistem mangrove karena ekosistem mangrove merupakan salah satu aset hutan di Indonesia yang berperan penting dalam proses pembangunan. Ekosistem mangrove apabila dikelola secara konservatif dapat meningkatkan dan membangun kegiatan perekonomian masyarakat secara berkelanjutan, khususnya masyarakat yang bermukim di daerah ekosistem mangrove. Tindakan konservatif pada ekosistem hutan mangrove dapat dilakukan salah satunya dengan cara rehabilitasi mangrove (Kordi dan Ghufran 2012).

Kegiatan rehabilitasi mangrove akan menambah kesadaran masyarakat untuk mengelola ekosistem yang berpotensi menghasilkan manfaat ekonomi serta membuktikan bahwa ekosistem mangrove mempunyai manfaat tanpa harus merusak ekosistem mangrove, maka perlu dilakukan kajian berupa perhitungan nilai valuasi ekonomi terhadap potensi ekosistem hutan mangrove. Perhitungan valuasi ekonomi ini ditujukan untuk memberikan gambaran manfaat apa saja yang ada dan melihat serta menghitung seberapa besar nilai ekonomi dalam pemanfaatan ekosistem mangrove sebagai upaya untuk mendukung konservasi.

\section{MATERI DAN METODE}

Materi utama yang digunakan dalam penelitian ini adalah pengamatan langsung dari lokasi penelitian dan data-data terkait yang bersumber dari instansi pemerintah maupun data dari masyarakat di Desa Kaliwlingi dan Desa Sawojajar. Data masyarakat yang dimaksud dapat berupa partisipasi, persepsi, dan aspirasi yang diperoleh dari kuisioner yang sudah dibagikan dan berkaitan dengan adanya valuasi ekonomi didaerah tersebut.

Metode yang digunakan dalam penelitian ini adalah metode deskriptif. Metode deskriptif bertujuan untuk deskripsikan, menggambarkan maupun melukiskan secara sistematis, faktual, dan akurat mengenai fakta-fakta, sifat-sifat serta hubungan antar fenomena yang akan diselidiki. (Arikunto, 2010).

Metode lain yang digunakan yaitu metode eksploratif yang bertujuan untuk menggali secara luas tentang sebab-akibat atau hal-hal yang mempengaruhi terjadinya sesuatu (Arikunto, 2010). Penggunaan kedua metode dalam penelitian ini dilaksanakan untuk mengkaji, mempelajari, 
ataupun mencari tahu permasalahan-permasalahan yang ada dimasyarakat maupun faktor alam yang mempengaruhi nilai valuasi ekonomi hutan mangrove di kedua lokasi penelitian, yaitu Desa Kaliwlingi dan Desa Sawojajar.

Penentuan lokasi penelitian ini dilakukan berdasarkan pentingnya perananan hutan mangrove bagi masyarakat di Desa Kaliwlingi dan Desa Sawojajar. Metode yang digunakan adalah metode purposive sampling. Metode ini diambil untuk tujuan tertentu dan biasanya dilakukan karena adanya beberapa pertimbangan yaitu adanya keterbatasan waktu, biaya maupun tenaga, tetapi tetap mengedepankan syarat-syarat prioritas utama yang harus dipenuhi (Suzana et al., 2011). Lokasi yang ditentukan diambil berdasarkan pertimbangan adanya beberapa aktivitas ekonomi masyarakat yang bersumber dari keberadaan hutan mangrove di Desa Kaliwlingi dan Desa Sawojajar, Kabupaten Brebes, Jawa Tengah.

Penentuan sampel penelitian yang digunakan dalam penelitian ini mengacu pada metode deskriptif eksploratif. Penelitian deskriptif eksploratif adalah suatu metode yang didapatkan dengan mengumpulkan data-data dari hasil sesi wawancara, catatan, lapangan, foto, dokumen pribadi, dokumen resmi, ataupun data-data lain yang nantinya dapat dijadikan panduan untuk mencari data baru dengan interpretasi yang tepat untuk menggambarkan kondisi dilapangan.

Sampel yang digunakan dalam hal ini diambil dari pendapat warga berupa sesi wawancara sehingga akan dihasilkan informasi mengenai valuasi ekonomi yang didapat karena keberadaan hutan mangrove baik dampak secara langsung maupun dampak yang ditimbulkan secara tidak langsung dan bagaimana tingkat kesesuaiannya hutan mangrove dengan progam konservasi. Statistik data demografi mengenai keadaan umum di kedua wilayah Desa Kaliwlingi dan Desa Sawojajar juga diperlukan. Data monografi tersebut berupa data mata pencaharian, jumlah penduduk, jenis kelamin, umur dan tingkat pendidikan masyarakat di wilayah tersebut.

\section{Metode Pengambilan Data Kajian Valuasi Ekonomi Ekosistem Hutan Mangrove}

Data primer diambil dari hasil sesi wawancara melalui pembagian kuisioner kepada masyarkat Desa Kaliwlingi dan Desa Sawojajar yang berkaitan dengan adanya atau keberadaan hutan mangrove dan nilai guna hutan mangrove baik secara langsung maupun secara tidak langsung. Lokasi ekosistem mangrove yang luas dan keterbatasan akses masyarakat terhadap sumberdaya mangrove, maka pemilihan desa sampel dilakukan dengan teknik cluster sampling. Cluster sampling atau areal sampling adalah metode pengambilan data secara acak dari kelompok - kelompok unit - unit terkecil (Riyastini, 2015).

Responden pada penelitian ini berjumlah masing-masing sebesar 100 orang yang berada di Desa Kaliwlingi dan Desa Sawojajar yang diambil dari $10 \%$ jumlah populasi mata pencaharian yang memiliki kaitan langsung dengan keberadaan ekosistem mangrove (Arikunto, 2010).

Data sekunder didapatkan melalui data dinas yang terkait sebagai salah satu data yang dijadikan data pendukung penelitian. Penelitian ini memerlukan beberapa data-data sekunder yang berhubungan dengan valuasi ekonomi ekosistem hutan mangrove di Desa Kaliwlingi dan Desa Sawojajar.

\section{Struktur dan Komposisi Vegetasi Mangrove}

Analisis data valuasi ekonomi yang utama berpusat pada metode perhitungan Total Economic Value (TEV). Nilai total ekonomi didapatkan melalui penambahan nilai guna (use value) maupun nilai tidak guna (non use value), namun ada tahapan lainnya seperti analisa SWOT. Menurut Bann (1998) Tahapan lain yang diperlukan dalam kajian valuasi ekonomi ekosistem hutan mangrove diantaranya :

a. Nilai Guna Langsung (DUV)

Manfaat langsung adalah nilai yang dihasilkan dari pemanfaatan langsung dari sumberdaya ekosistem hutan mangrove.

DUV = DUV1 + DUV2 + DUV3..... + DUVn (Rp/tahun)

DUV = Nilai Guna Langsung

DUV1 = Manfaat langsung, total dari hasil perikanan tangkap

DUV2 = Manfaat langsung, total dari hasil tambak

DUV3 = Manfaat langsung, total hasil pembibitan mangrove 
DUV4 = Manfaat langsung, total dari hasil penjual hasil mangrove

DUV5 = Manfaat langsung, total dari hasil penjual hasil laut

DUV6 = Manfaat langsung, total dari hasil pengolah hasil laut

DUV7 = Manfaat langsung, total dari hasil pengepul hasil laut

b. Nilai Guna Tidak Langsung (IUV)

Nilai guna tidak langsung adalah nilai yang dirasakan secara tidak langsung terhadap barang dan jasa yang dihasilkan sumberdaya dan lingkungan.

IUV = IUV1+ IUV2 ..... + IUVn (Rp/tahun)

IUV1 = Nilai guna tidak langsung sebagai Hybrid engineering

IUV2 = Nilai guna tidak langsung alat pemecah ombak

c. Nilai Pilihan (OV)

Nilai pilihan merupakan nilai guna dari sumber daya alam dan lingkungan yang dapat digunakan di masa mendatang (manfaat yang ditekankan ialah keanekaragaman hayatinya. Nilai keanekaragaman hayati hutan mangrove Indonesia termasuk di Desa Kaliwlingi dan Desa Sawojajar yaitu sebesar US\$1,500/ $\mathrm{km}^{2} /$ tahun atau US\$15/ha/tahun

OV $=$ US $\$ 15 /$ ha/tahun $x$ Luas ekosistem mangrove (Rp/tahun)

OV = Option Value

d. Nilai Keberadaan (EV)

Nilai keberadaan adalah nilai yang diberikan secara semata-mata karena adanya kepedulian terhadap keberadaan suatu habitat di suatu ekosistem. Metode yang digunakan adalah metode Contingent Valuation Method (CVM) dengan menentukan nilai WTP (Willingness To Pay).

$\mathrm{EV}=\sum_{1}^{n}=1$ (EVi) / n (Rp/tahun)

$E V=$ Nilai WTP dari responden ke-i

$\mathrm{n}=$ Jumlah responden

e. Nilai Warisan (BV)

Nilai warisan merupakan nilai ekonomi yang diperoleh dari manfaat pelestarian sumberdaya atau ekosistem yang dapat dipergunakan dan dikembangkan masyarakat di generasi masa mendatang.
BV = DUV $\times 10 \%$
BV = Nilai warisan
DUV = Nilai guna langsung

f. Nilai Total Ekonomi (TEV)

Nilai ekonomi total ini adalah nilai yang didapat dari penjumlahan seluruh nilai manfaat ekonomi sumberdaya ekosistem mangrove yang sudah diidentifikasi dan dikuantifikasikan sebelumnya.

TEV = Nilai guna + Tidak ada nilai guna (Rp/tahun)

$\mathrm{TEV}=(\mathrm{DUV}+\mathrm{IUV}+\mathrm{OP})+(\mathrm{EV}+\mathrm{BV})(\mathrm{Rp} / \mathrm{tahun})$

$\mathrm{TEV}=$ Total Economic Value / Nilai Ekonomi Total

DUV = Direct Use Value / Nilai Guna Langsung

IUV = Indirect Use Value / Nilai Guna Tidak Langsung

$\mathrm{OP}=$ Option Value / Nilai Pilihan

$\mathrm{EV}=$ Existence Value / Nilai Keberadaan

$\mathrm{BV}=$ Bequest Value / Nilai Warisan

\section{Analisis SWOT}

Strategi pengelolaan ekosistem hutan mangrove di dua lokasi penelitian yaitu Desa Kaliwlingi dan Desa Sawojajar disusun dari data-data yang sudah diperoleh dengan metode analisis SWOT. Analisis SWOT dilakukan dengan menerapkan kriteria kesesuaian dengan data kuantitatif dan deskripsi keadaan (faktor internal dan faktor eksternal). Menurut Usman dan Purnomo (2008) Tujuan dari analisis SWOT adalah untuk menentukan faktor-faktor strategis baik faktor internal maupun faktor eksternal yang akan menentukan keberhasilan program rehabilitasi mangrove yang meliputi: 
a. Faktor internal (strengths dan weakness) merupakan faktor faktor yang dianggap sebagai kekuatan dan kelemahan dalam pengelolaan rehabilitasi mangrove dilihat dari sumberdaya mangrove, sumberdaya manusia, infrastruktur, maupun kelembagaan.

b. Faktor eksternal (opportunities dan threats) adalah faktor faktor yang berasal dari luar lingkup pengelolaan rehabilitasi mangrove yang diperkirakan dapat mendukung ataupun menghambat program rehabilitasi mangrove seperti politik, sosial-ekonomi, dan teknologi.

Nilai dari tabel IFAS dan EFAS dapat dilakukan melalui tahapan-tahapan sebagai berikut:

1. Menentukan faktor internal (strength dan weakness) dan eksternal (opportunity dan threat) dari hasil wawancara.

2. Memberikan skala penilaian (rating scale) dengan berdasarkan pada skala Linkert, seperti Tabel Rating dapat diperoleh berdasarkan asusmsi peneliti setelah melihat kenyataan di lapangan yang dikaitkan dengan mengacu pada penelitian sejenis yang pernah dilakukan sebelumnya.

\section{HASIL DAN PEMBAHASAN}

Daerah pesisir Brebes mempunyai kedudukan lebih dekat dengan perairan laut yang memiliki panjang pantai $\pm 72,93 \mathrm{~km}$ sehingga daerah ini mempunyai potensi sebagai wilayah pesisir yang sangat baik. Wilayah Brebes berpotensi besar dalam mengembangkan dunia maritimnya, yaitu dengan bidang industri, ekonomi dan budaya. Potensi unggulan yang dapat dikembangkan adalah sektor pariwisata khususnya obyek wisata hutan mangrove serta mempunyai keunikan dan ciri khas tersendiri terhadap keanekaragaman jenis mangrovenya. Jenis-jenis mangrove di kedua desa ini di dominasi oleh Rhizophora sp. dan Avicennia sp.

Lokasi penelitian terletak di salah satu contoh wilayah pesisir di Kabupaten Brebes yang memiliki ekosistem hutan mangrove yang cukup luas tepatnya terdapat di 2 desa yaitu Desa Kaliwlingi dan Desa Sawojajar. Kedua desa pesisir ini memiliki letak yang berdekatan. Jarak kedua desa ini sangat dekat namun keduanya terletak di kecamatan yang berbeda. Desa Kaliwlingi termasuk di Kecamatan Brebes, sementara Desa Sawojajar termasuk di Kecamatan Wanasari.

Kedua desa ini yang terletak di kawasan pesisir mempunyai ekosistem hutan mangrove yang cukup luas serta berdampingan dengan pemukiman penduduk. Ekosistem mangrove yang sangat dekat dengan masyarakat karena mangrove dapat bemanfaat secara langsung maupun tidak langsung. Desa Kaliwlingi merupakan desa hasil rehabilitasi mangrove yang tergolong berhasil karena mempunyai kelompok tani mangrove yang aktif dalam melakukan penanaman dan membuat masyarakatnya giat untuk mengembangkan inovasi produk dengan memanfaatkan mangrove sebagai sarana untuk menambah perekonomian desa. Desa Sawojajar merupakan contoh desa hasil rehabilitasi mangrove yang sedang baru memulai untuk melakukan kegiatan aktif dalam penanaman mangrove dan mengembangkan hasil produk yang dihasilkan oleh ekosistem mangrove. Perbandingan yang cukup mendasar dan signifikan di kedua desa ini patut dikaji lebih lanjut, maka diperlukan penelitian kajian tentang valuasi ekonomi ekosistem hutan mangrove di Desa Kaliwlingi dan Desa Sawojajar.

\section{Identifikasi Nilai Guna Ekosistem}

Penelitian ini menggunakan metode wawancara yang melibatkan 100 responden masyarakat tiap desa yang terletak di Desa Kaliwlingi dan Desa Sawojajar yang bermata pencaharian berhubungan langsung dengan ekosistem hutan mangrove. Ekosistem mangrove yang sangat dekat dengan pemukiman membuat masyarakat merasakan manfaat ekonomi dari mangrove. Hasil perhitungan responden Desa Kaliwlingi menyatakan bahwa sebesar 65\% mengetahui bahwa ekosistem hutan mangrove memiliki manfaat ekonomi, sementara di Desa Sawojajar hanya berjumlah $23 \%$ responden yang mengetahui manfaat ekonomi mangrove. Manfaat ekosistem hutan mangrove dapat diidentifikasi dengan melihat nilai guna (use value), tidak ada nilai guna (non use value) dan nilai total ekonomi (total economic value) hutan mangrove. Berikut ini nilai guna ekosistem mangrove di Desa Kaliwlingi dan Desa Sawojajar

Nilai Guna Langsung (DUV) : Nilai guna langsung dalam ekosistem hutan mangrove adalah nilai guna yang didapatkan langsung dan berasal dari sumberdaya alam. Nilai guna 
langsung ini merupakan nilai guna yang paling besar dimanfaatkan oleh masyarakat di Desa Kaliwlingi dan Desa Sawoajajar. Pemanfaatan ekosistem hutan mangrove di Desa Kaliwlingi mencapai nilai sebesar Rp 9.469.800.000, sedangkan Desa Sawoajajar nilai gunanya lebih kecil yaitu sebesar Rp 3.401.020.000. Masyarakat di kedua desa memiliki mata pencaharian yang berkaitan langsung dengan ekosistem mangrove dan laut. Mata pencaharian di Desa Kaliwlingi mencakup 9 bidang seperti nelayan tangkap, pembuatan garam rebus, tambak bandeng intensive, tambak bandeng alami, tambak budidaya kepiting soka, penangkap kepiting, pembibitan mangrove, pengepul hasil tangkapan dan pembuatan bandeng cabut duri. Desa Sawojajar hanya memiliki 7 bidang mata pencaharian yang meliputi nelayan tangkap, tambak bandeng intensive, tambak bandeng alami, tambak budidaya kepiting soka, penangkap kepiting, pembibitan mangrove dan pengepul hasil tangkapan.

Desa Kaliwlingi dan Desa Sawojajar memiliki mata pencaharian yang didominasi oleh pekerjaan nelayan dan petambak ikan, hal ini karena letak geofrafis kedua desa yang berada di kawasan pesisir. Nelayan di Desa Kaliwlingi memiliki presentase sebesar $45 \%$ dan petambak ikan sebesar 35\%, sementara Desa Sawoajajar mempunyai presentase dominasi nelayan dan petambak yang lebih besar yaitu nelayan sebesar $50 \%$ dan petambak ikan $41 \%$. Nelayan penangkap ikan dan petambak adalah salah satu pekerjaan utama yang sering dilakukan masyarakat di kedua desa. Nelayan biasanya akan menangkap ikan pada waktu siang hari dan malam hari dengan menggunakan alat tangkap berupa jarring gill net dan aret. Jenis hasil tangkapan nelayan sendiri didominasi oleh ikan kakap merah, tengiri, kembung dan rajungan.

Petambak ikan bandeng di Desa Kaliwlingi maupun Desa Sawojajar dibagi menjadi dua jenis yaitu petambak bandeng alami dan petambak bandeng intensive. Tambak alami dan tambak intensive dibedakan berdasarkan cara memberi pakan, cara perawatan, jangka waktu panen dan hasil panen ikan. Kedua desa ini memiliki perbedaan yang cukup signifikan pada pengelolaan tambak mereka. Masyarakat di Desa Kaliwlingi lebih banyak memilih metode tambak intensive, sementara masyarakat Desa Sawojajar lebih banyak memilih metode tambak alami. Metode pemberian pakan tambak alami dirasa lebih murah karena tidak memerlukan pakan ekstra dan nutrisi yang lebih dibandingkan dengan tambak intensive, sehingga tidak membutuhkan modal yang cukup banyak. Lama panen ikan tambak intensive memang memerlukan waktu yang lebih lama dibandingkan dengan tambak alami, namun hasil ikan yang didapatkan akan lebih banyak dibandingkan dengan tambak alami. Tambak intensive juga biasanya mempunyai penyekat disetiap ujungnya yang disebut waring yang biasanya terbuat dari bambu.

Nilai guna langsung lain didapatkan dari pembibitan mangrove. Desa Kawlingi sendiri memiliki kelompok tani bernama "Mangrove Sari" sementara Desa Sawojajar bernama "Wana Lestari". Presentase nilai guna pembibitan mangrove yang lebih besar berada di Desa Kaliwlingi yaitu sebanyak $2 \%$ sementara Desa Sawojajar hanya sebesar $1 \%$. Desa Sawojajar memiliki luasan sebesar 81 ha yang lebih kecil dibandingkan dengan luasan Desa Kaliwlingi yaitu sebesar 180 ha. Profesi pembibit mangrove di kedua desa ini tidak hanya mempunyai 1 profesi saja, namun biasanya pembibit akan tetap membibitkan propagul mangrove tiap 3 minggu. Pemasaran bibit mangrove dari Desa Kaliwlingi maupun Desa Sawojajar ini berasal dari pemerintah maupun swasta yang membutuhkan bibit mangrove.

Nilai guna langsung lainnya didapatkan dari beberapa kegiatan yang lain contohnya di Desa Kaliwlingi yang pendapatannya didapat dari penangkap kepiting, tambak budidaya kepiting soka, pengepul hasil tangkapan laut, pembuat garam rebus dan pembuat bandeng cabut duri. Desa Sawojajar memiliki kegiatan yang hampir sama namun tidak lebih banyak apabila dibandingkan dengan Desa Kaliwlingi. Kegiatan menangkap kepiting biasanya dilakukan pada malam hari dengan berbekal jaring dan alat penerangan berupa senter. Tempat mencari kepitng biasanya terletak disekitar ekosistem mangrove karena mangrove biasanya dijadikan sebagai tempat mencari makan dan daerah memijah bagi kepiting.

Budidaya kepiting soka juga menjadi kegiatan yang cukup menambah pendapatan nilai guna. Jenis kepiting ini merupakan jenis kepiting bakau yang seluruh tubuhnya lunak akibat dari pergantian cangkang, capit dan kaki sehingga banyak dicari karena permintaan pasar meningkat setiap tahunnya. Ekosistem hutan mangrove di Desa Kaliwlingi memiliki nilai ekonomi yang lebih besar dibandingkan Desa Sawojajar apabila dilihat dari perhitungan nilai guna langsungnya, hal ini karena Desa Kaliwlingi sudah memiliki cakupan wilayah ekosistem mangrove yang cukup besar 
dan masyarakat Desa Kaliwlingi lebih kreatif dalam mengembangkan sumberdaya alam yang ada sehingga pendapatan masyarakat juga bertambah.

Nilai Guna Tidak Langsung (IUV) : Nilai guna tidak langsung adalah nilai guna yang secara tidak langsung dirasakan manfaatnya oleh masyarakat yang dihasilkan secara tidak langsung dari adanya keberadaan mangrove. Nilai guna langsung ekosistem mangrove dapat berperan sebagai pencegah abrasi,penahan gelombang, penyerapan karbon dan juga penyediaan makanan bagi biota yang hidup disekitar ekosistem mangrove (kepiting, kerang, udang). Menurut Zen dan Fitria (2013) penilaian hutan mangrove secara fisik dapat diestimasi dengan melihat dari fungsi hutan mangrove sebagai penahan abrasi dengan cara menghitung replacement cost atau biaya pengganti yang digunakan untuk pembuatan bangunan pantai atau pemecah ombak.

Perhitungan nilai guna tidak langsung di Desa Kaliwlingi mencapai total sebesar Rp 1.500.000.000 yang terdiri dari adanya alat pemecah ombak/APO dengan panjang $750 \mathrm{~m}^{2}$ yang nilai totalnya mencapai 200.000 .000 dan hybrid engineering sepanjang $1 \mathrm{~km}$ senilai 1.300.000.000. Desa Sawojajar memiliki nilai total yang lebih besar dibandingkan dengan Desa Kaliwlingi karena memiliki 3 bangunan pantai yang berfungsi untuk mencegah adanya abrasi diantaranya alat pemecah ombak/APO, hybrid engineering dan geotube. Alat pemecah ombak/APO di Desa Sawojajar memiliki panjang seluas $100 \mathrm{~m}^{2}$ dengan nilai total sebesar 150.000.000, hybrid engineering sepanjang $901 \mathrm{~m}$ senilai 1.270.000.000 dan geotube sepanjang $500 \mathrm{~m}$ yang mempunyai nilai total mencapai 500.000.000., sehingga total nilai guna tidak langsung di Desa Sawojajar mencapai Rp 1.920.000.000. Bangunan pantai yang dibangun di Desa Kalwlingi dan Desa Sawojajar adalah bantuan dari pemerintah melalui KKP.

Usaha lain yang dilakukan untuk mencegah terjadinya abrasi adalah melakukan penanaman mangrove yang rutin di Desa Kaliwlingi dan Desa Sawojajar. Penanaman mangrove dapat terjadi karena adanya bantuan-bantuan dari pihak lain. Bantuan ini dapat bersumber dari instansi pemerintah, swasta maupun akademisi. Desa Kaliwlingi yang mendapat bantuan bibit mangrove untuk penanaman dari yayasan Kehati, Lebah Nusantara, OISCA, Tokyo Marine Ichido dan Toyota. Desa Sawoajajar mendapat bantuan bibit mangrove dari pemerintah melalui KKP, DKP Jateng, OISCA dan Global Environment Facility/GEF. Desa Sawojajar lebih rentan akan adanya abrasi sehingga sering mendapatkan bantuan yang lebih banyak baik dari pemerintah maupun non pemerintah karena diduga pengamanan pantai alami (ekosistem mangrove) di Desa Sawojajar yang lebih kecil dibandingkan Desa Kaliwlingi, hal ini dibuktikan dengan adanya luasan ekosistem mangrove yang cukup signifikan pada kedua desa. Desa Sawojajar memiliki luasan ekosistem mangrove sebesar 81 ha, sedangkan luasan ekosistem mangrove di Desa Kaliwlingi adalah sebesar 180 ha, sehingga urgensi penanganan untuk mencegah adanya abrasi akan lebih diutamakan pada Desa Sawojajar.

Ekosistem hutan mangrove di kedua desa memiliki kondisi yang semakin membaik tiap tahunnya serta dirasa berhasil dalam menjaga pergerakan air laut sehingga air laut tidak dapat memasuki kawasan pemukiman masyarakat. Kedua desa tersebut juga berhasil menumbuhkan rasa kesadaran bagi warganya untuk melakukan penanaman mangrove secara mandiri. Kegiatan rutin juga sering diadakan oleh penduduk desa, diantaranya yaitu membentuk kelompok peduli mangrove maupun bersedia mengikuti sosialisasi mengenai fungsi dan manfaat mangrove.

Nilai Pilihan (OV) : Nilai pilihan adalah suatu nilai ekonomi yang didapatkan dari potensi pemanfaatan langsung maupun tidak langsung sumberdaya alam sehingga dapat dimanfaatkan untuk masa yang akan datang. Nilai pilihan dapat dilihat dari adanya nilai biodiversitas / keanekaragaman yang didapatkan dari suatu wilayah. Penelitian ini dilakukan untuk menentukan nilai pilihan yang dilihat dari adanya nilai biodiversitas mangrove. Desa Kaliwlingi dan Desa Sawojajar memiliki jenis mangrove yang sama yaitu Rhizophora sp. dan Avicennia sp. Spesies mangrove yang dimaksud adalah Rhizophora mucronata, Avicennia alba dan Avicennia marina. Ketiga spesies ini tumbuh subur di kedua desa karena mempunyai tipe substrat yang sama berupa lumpur, sehingga cocok untuk ditanami jenis tersebut. Program rehabilitasi mangrove di kedua desa cukup berhasil memiliki dampak yang besar untuk meningkatkan dan melestarikan ekosistem hutan mangrove.

Menurut Ruintenbeek (1992) hutan mangrove Indonesia mempunyai nilai biodiversity sebesar U\$1500/km²/tahun atau setara 15/ha/tahun, nilai pilihan ini dapat digunakan diseluruh 
hutan mangrove di Indonesia jika ekosistem hutan mangrovenya tetap terpelihara secara alami. Perhitungan nilai pilihan didapatkan melalui perkalian nilai asumsi, jumlah kurs dolar dan luas ekosistem mangrove (Ariftia, 2014). Kurs dolar yang digunakan dalam perhitungan ini adalah sebesar Rp 14.903,00 (29 September 2018). Nilai pilihan ekosistem hutan mangrove di Desa Kaliwlingi adalah sebesar Rp 40.238.100,00 dengan luasan hutan mangrove sebesar 180 ha. Desa Sawojajar memiliki nilai pilihan yang jumlahnya lebih sedikit dari Desa Kaliwlingi yaitu hanya sebesar Rp 18.107.145,00 karena luasan mangrove di Desa Sawojajar hanya sebesar 81 ha.

\section{Tidak Ada Nilai Guna}

Nilai Keberadaan atau existence value merupakan manfaat yang dirasakan oleh masyarakat setempat atas adanya keberadaan ekosistem hutan mangrove di sekitar mereka setelah manfaat lainnya di keluarkan (Purnamawati et al.,2015). Nilai keberadaan dapat peroleh dari hasil perkalian antara nilai median Wilingness To Pay (WTP) per tahun dengan populasi penduduk di sekitar ekosistem hutan mangrove. Nilai total rata-rata WTP per tahun adalah estimasi dari nilai keberadaan ekosistem hutan mangrove di Desa Kaliwlingi maupun di Desa Sawojajar. Wilingness To Pay / WTP merupakan kesediaan individu untuk membayar terhadap suatu kondisi lingkungan atau penilaian terhadap sumberdaya alam dan jasa alami dalam rangka memperbaiki kualitas lingkungan. Nilai keberadaan di Desa Kaliwlingi setelah dihitung adalah sebesar Rp 2.245.720.000 dari jumlah populasi penduduk sebesar 9.764 orang yang dikalikan dengan nilai rata-rata WTP sebesar Rp 230.000/orang. Desa Sawojajar memiliki nilai keberadaan yang lebih kecil dibandingkan Desa Kaliwlingi yaitu sejumlah Rp 1.676.180.000 yang didapatkan dari jumlah populasi penduduk sebanyak 15.238 orang yang dikalikan dengan nilai rata-rata WTP Desa Sawojajar yaitu sebesar Rp 110.000/orang.

Nilai rata-rata WTP di Desa Kaliwlingi lebih besar dari pada Desa Sawojajar karena masyarakat disana mempunyai pengetahuan yang cukup tinggi tentang mangrove dan kreatif dalam memanfaatkan mangrove sehingga dapat menghasilkan produk-produk yang berbahan dasar mangrove. Faktor lain yang mempengaruhi adalah dari adanya tempat ekowisata mangrove yang lebih unggul di Desa Kaliwlingi membuat nilai WTP di desa ini meningkat.

Desa Sawojajar memiliki banyak penduduk yang masih minim pengetahuan akan fungsi dan manfaat dari ekosistem hutan mangrove. Pengetahuan dan pemanfaatan mangrove yang kurang ini diduga berdampak pada kesadaran yang kecil untuk menjaga dan memperbaiki kualitas lingkungan. Faktor lain juga dapat disebabkan oleh lebih sedikitnya mata pencaharian utama masyarakat di Desa Sawojajar yang langsung berhubungan dengan ekosistem mangrove. Mayoritas pekerjaan utama penduduk di Desa Sawojajar adalah nelayan kapal besar sehingga pekerjaan mereka tidak sepenuhnya bergantung pada adanya ekosistem hutan mangrove. Penduduk yang mempunyai pekerjaan nelayan kapal besar akan hanya mengambil ikan di sekitar ekosistem mangrove apabila mereka sedang tidak berlayar / libur, sehingga kesadaran untuk menjaga ekosistem mangrove kecil. Hasil nilai Wilingness To Pay disuatu wilayah diduga dapat dijadikan sebagai tolak ukur terhadap keadaan di lapangan.

Nilai warisan adalah nilai ekonomi yang didapatkan dari hasil manfaat pelestarian suatu sumberdaya atau ekosistem sehingga dapat berguna untuk generasi di masa depan. Nilai warisan akan optimal dengan didukung oleh pengelolaan yang sustainable / berkelanjutan. Menurut Ruitenbeek (1992) nilai warisan ekosistem hutan mangrove diperkirakan sebesar $10 \%$ dari nilai manfaat langsung ekosistem mangrove tersebut. Nilai guna langsung di Desa Kaliwlingi adalah sebesar Rp 7.387.400.000 sehingga nilai warisannya adalah sebesar Rp 738.740.000. Desa Sawojajar memiliki jumlah nilai warisan yang lebih kecil dibandingkan Desa Kaliwlingi yaitu sebesar Rp 173.227.000, hasil ini didapatkan dari perkalian nilai guna langsung yang dikalikan dengan $10 \%$.

Pelestarian suatu sumberdaya atau ekosistem hutan mangrove di Desa Kaliwlingi dan Desa Sawojajar memiliki manfaat yang paling utama yaitu sebagai pelindung dari gelombang dan air pasang agar desa terhindar dari terjadinya abrasi. Ekosistem hutan mangrove dapat menjadi warisan di masa mendatang karena mangrove sendiri disamping mempunyai fungsi secara fisik juga mempunyai fungsi ekologis dan fungsi ekonomi. Ekosistem mangrove secara ekologis dapat berperan sebagai kawasan mencari makan (feeding ground), daerah asuhan (nursery ground) dan 
daerah memijah (spawning ground) bagi organisme yang berada di sekitar ekosistem hutan mangrove.

Nilai warisan yang sangat berharga ini perlu dijaga dan perlu adanya upaya untuk melakukan rehabilitasi ekosistem hutan mangrove secara berkelanjutan di Desa Kaliwlingi maupun di Desa Sawojajar. Kegiatan rehabilitasi mangrove di Desa Kaliwlingi maupun Desa Sawojajar banyak di dukung dari instansi pemerintah maupun swasta. Desa Kaliwlingi biasanya mendapatkan bantuan yang berasal dari instansi yayasan Kehati, Lebah Nusantara, OISCA, Tokyo Marine Ichido dan Toyota. Desa Sawoajajar mendapat bantuan pemerintah melalui KKP, OISCA dan Global Environment Facility/GEF. Rehabilitasi harus serta diiringi dengan keikutsertaan masyarakat supaya pengelolaan ekosistem hutan mangrove dapat berkelanjutan.

Tabel 1. Review Nilai Total Ekonomi Ekosistem Hutan Mangrove di Desa Kaliwlingi, Kabupaten Brebes, Jawa Tengah

\begin{tabular}{llrr}
\hline No & Jenis Nilai Guna & Nilai Total (Rp) & Presentase (\%) \\
\hline 1 & Nilai Guna (Use Value) & & 62,02 \\
& Nilai Guna Langsung & 7.387 .400 .000 & 12,60 \\
& Nilai Guna Tidak & 1.500 .000 .000 & 0,33 \\
\hline & Langsung & 40.238 .100 & \\
& Nilai Pilihan & Rp 9.927.638.100 & 18,86 \\
& Use Value & 2.245 .720 .000 & 6,20 \\
\hline 2 & Tidak Ada Nilai Guna (Non Use Value) \\
& Nilai Keberadaan & 738.740 .000 & 100 \\
\hline & Nilai Warisan & Rp 2.984.460.000 &
\end{tabular}

Tabel 2. Review Nilai Total Ekonomi Ekosistem Hutan Mangrove di Desa Sawojajar, Kabupaten Brebes, Jawa Tengah

\begin{tabular}{|c|c|c|c|}
\hline No & Jenis Nilai Guna & Nilai Total (Rp) & Presentase (\%) \\
\hline \multirow[t]{5}{*}{1} & Nilai Guna (Use Value) & & \\
\hline & Nilai Guna Langsung & 1.732 .270 .000 & 31,38 \\
\hline & Nilai Guna Tidak Langsung & 1.920 .000 .000 & 34,80 \\
\hline & Nilai Pilihan & 18.107.145 & 0,32 \\
\hline & Use Value & $\operatorname{Rp} 3.670 .377 .145$ & \\
\hline \multirow[t]{5}{*}{2} & Tidak Ada Nilai Guna (Non L & & \\
\hline & Nilai Keberadaan & 1.676.180.000 & 30,36 \\
\hline & Nilai Warisan & 173.227 .000 & 3,14 \\
\hline & Non Use Value & $\operatorname{Rp~1.849.407.000~}$ & \\
\hline & Total Nilai Ekonomi & Rp 5.519.784.145 & 100 \\
\hline
\end{tabular}

Desa Kaliwlingi memiliki masyarakat yang tergolong sudah sangat baik dalam mendukung kegiatan rehabilitasi mangrove bahkan ikut ambil bagian dalam penanaman mangrove. Masyarakat Desa Kaliwlingi aktif dalam mengikuti adanya program penanaman maupun melakukan penanaman secara mandiri, hal ini terbukti dengan adanya hasil kuisioner yang diambil dari 100 responden, sebanyak 65 orang menjawab pernah berperan dalam kegiatan rehabilitasi 
mangrove. Desa Sawojajar memiliki keadaan yang berbanding terbalik dengan hasil Desa Kaliwlingi yaitu hanya sebesar 37 orang dari 100 responden yang menjawab pernah berperan dalam kegiatan rehabilitasi mangrove. Mayoritas mata pencaharian penduduk Desa Sawojajar adalah sebagai nelayan tangkap kapal besar yang penghasilannya tidak langsung berkaitan dengan adanya ekosistem mangrove, sehingga menyebabkan rasa peduli terhadap kegiatan rehabilitasi ekosistem mangrove juga tidak sebesar di Desa Kaliwlingi.

Nilai total ekonomi merupakan nilai-nilai hasil penjumlahan dari seluruh nilai ekonomi yang terkandung di dalam sumberdaya alam (ekosistem hutan mangrove) yang telah diidentifikasi dan dikuantifikasikan. Nilai ekonomi total yang ada tersebut ialah sebuah pendekatan untuk mengetahui potensi sumberdaya alam yang ada di kawasan Desa Kaliwlingi dan Desa Sawojajar. Nilai total ekonomi di Desa Kaliwlingi adalah sebesar Rp 12.912.098.100/tahun, nilai ini diperoleh dari penjumlahan adanya nilai guna / use value sejumlah $\mathrm{Rp}$ 9.927.638.100/tahun dan tidak ada nilai guna / non-use value yaitu sebesar Rp 2.984.460.000/tahun. Nilai guna di Desa Kaliwlingi meliputi nilai guna langsung dengan presentase paling tinggi yaitu 62,02\%, diikuti dengan presentase nilai guna tidak langsung sebesar $12,60 \%$ dan nilai keberadaan dengan presentase $0,33 \%$. Kategori tidak ada nilai guna Desa Kaliwlingi meliputi nilai keberadaan dengan presentase $18,86 \%$ dan nilai warisan sebanyak $6,20 \%$.

Nilai total ekonomi di Desa Sawojajar lebih kecil dibandingkan dengan Desa Kaliwlingi yaitu hanya sejumlah Rp 5.519.784.145/tahun dimana hasil ini didapatkan dari nilai guna sebesar Rp 3.670.377.145/tahun dan tidak ada nilai guna sebesar Rp 1.849.407.000/tahun. Nilai guna Desa Sawojajar meliputi nilai guna langsung dengan presentase $31,38 \%$, nilai guna tidak langsung dengan presentase paling tinggi sebesar $34,80 \%$ dan nilai keberadaan dengan presentase $0,32 \%$. Kategori tidak ada nilai guna meliputi nilai keberadaan dengan presentase cukup tinggi sebesar $30,36 \%$ dan nilai warisan sebesar $3,14 \%$.

Desa Kaliwlingi dan Desa Sawojajar rutin untuk melakukan rehabilitasi kondisi lingkungan ekosistem hutan mangrove yang dapat berdampak pada nilai total ekonomi ekosistem hutan mangrove. Ekosistem hutan mangrove yang tidak baik juga akan berdampak pada kegiatan ekonomi masyarakat.

Ekosistem mangrove hasil program rehabilitasi yang semakin baik dapat juga dimanfaatkan sebagai daerah ekowisata mangrove di Desa Kaliwlingi dan Desa Sawojajar. Lahan ehabilitasi mangrove dimanfaatkan masyarakat desa dalam bentuk dibukanya daerah ekowisata mangrove "Taman Mangrove Pandansari" di Desa Kaliwlingi dan ekowisata mangrove "Pulau Cemara" di Desa Sawojajar. Ekowisata di kedua desa dapat meningkatkan nilai valuasi ekonomi dan pendapatan masyarakat di kedua desa. Kegiatan valuasi ekonomi juga dapat mendorong adanya kesadaran masyarakat sendiri terhadap kepedulian menjaga ekosistem hutan mangrove.

Nilai total ekonomi ekosistem hutan mangrove di Desa Kaliwlingi dan Desa Sawojajar menunjukan karakteristik daerah tersebut. Desa Kaliwlingi memiliki nilai total ekonomi cukup besar yang didominasi oleh kegiatan-kegiatan nilai guna langsung yang berasal dari kegiatan ekonomi aktif seperti penangkapan ikan oleh nelayan, pembuatan garam rebus, tambak bandeng alami, tambak bandeng intensive, adanya budidaya kepiting soka, penangkap kepiting, pembuat bandeng cabut duri, pembibitan mangrove dan pengepul hasil tangkapan. Nilai total ekonomi di Desa Sawojajar unggul pada kategori nilai guna tidak langsung yaitu pada fungsi bangunan pantai seperti adanya alat pemecah ombak/APO, hybrid engineering dan geotube untuk sebagai pencegah abrasi.

Kedua desa menunjukan perbedaan yang cukup signifikan, hal ini dapat dilihat dari adanya kegiatan ekonomi masyarakat di Desa Kaliwlingi sangat berhubungan erat dengan adanya ekosistem mangrove, sementara kegiatan ekonomi di Desa Sawojajar tidak langsung berkaitan dengan ekosistem mangrove. Perbandingan kedua desa menunjukan masyarakat Desa Kaliwlingi memiliki pengetahuan yang baik dan kreatifitas yang tinggi untuk mengembangkan produk yang berasal dari laut maupun dari ekosistem mangrove. Desa Sawojajar yang kurang memanfaatkan sisi ekonomi dari mangrove sendiri pun, pada keadaan di lapangan lebih unggul dalam pengamanan pesisir berupa bangunan pantai yang lebih bermacam untuk pencegah adanya abrasi. Perbedaan ini menunjukan bahwa tiap-tiap desa mempunyai sisi kelebihan dan kekurangan masing-masing. 


\section{Analisa SWOT}

Strategi untuk menghitung valuasi ekonomi hutan mangrove dilakukan melalui proses analisis dengan mempertimbangkan semua aspek yang berkaitan dengan kegiatan ekonomi di kedua desa. Aspek tersebut antara lain meliputi aspek ekologi, sosial-ekonomi dan kelembagaan. Data-data mengenai aspek ekologi didapatkan melalui data sekunder yang diambil secara bersamaan pada saat penelitian berlangsung. Aspek sosial ekonomi dan kelembagaan penelitian ini didapatkan melalui hasil wawancara dengan responden dan tokoh masyarakat yang langsung berkaitan dengan pengelolaan ekosistem mangrove di kedua desa. Data sekunder untuk kajian valuasi ekonomi ekosistem hutan mangrove ini didapatkan dari berbagai instansi terkait.

Analisis SWOT (Strength, Weakness, Opportunity, Threat) pada penelitian ini meliputi identifikasi faktor internal, faktor eksternal, nilai IFAS dan EFAS, matriks SWOT, alternatif strategi, pengembangan dan rekomendasi pengembangan. Identifikasi faktor internal dan faktor eksternal adalah tahapan pertama yang dilakukan adalah mencari faktor-faktor apa saja yang berpengaruh dan menonjol di lapangan. Identifikasi ini didapatkan melalui kuisioner, data maupun wawancara pihak ahli terkait sehingga dapat tercerminkan secara menyeluruh dan nantinya dapat diklasifikasikan menurut tipenya. Tahapan kedua adalah melakukan perhitungan rating yang didapatkan dari penilaian rata-rata kuisioner dan pembobotan yang didapatkan dari penilaian para ahli sehingga akan didapatkan skor akhir yang akan digambarkan dalam matriks SWOT. Tahapan terakhir adalah merencanakan alternatif strategi pengembangan dan memberikan rekomendasi yang tepat untuk kedua desa. Tujuan tahapan ini supaya potensi yang sudah ada dapat dipertahankan maupun lebih ditingkatkan dan potensi yang belum timbul atau masih kurang dapat segara dilakukan pengembangan lebih lanjut.

Perhitungan nilai IFAS (Internal Strategic Factor Analysis Summary) di Desa Kaliwlingi sebesar 0.59 yang terdiri dari jumlah kekuatan (strength) sebesar 1.80 dan kelemahan (weakness) yaitu 1.21. Nilai EFAS (External Strategic Factor Analysis Summary) yang didapatkan adalah 1.08 yang terdiri dari jumlah nilai peluang (opportunity) sebesar 2.08 dan ancaman (threat) sebesar 1.00. Hasil perhitungan ini mengarahkan matrik berada pada kuadran I dimana nilai yang dihasilkan keduanya positif. Nilai bobot dan rating dari Strength dan Opportunity (S-O) menunjukan urgensi penanganan dan tingkat kepentingan yang tinggi. Matrik SWOT di sajikan pada Gambar 1.

Nilai IFAS (Internal Strategic Factor Analysis Summary) pada Desa Sawojajar adalah sebesar -1.25 yang terdiri dari jumlah kekuatan (strength) sebesar 0.99 dan kelemahan (weakness) yaitu 2.24. Nilai EFAS (External Strategic Factor Analysis Summary) yang didapatkan adalah -0.24 yang terdiri dari jumlah nilai peluang (opportunity) sebesar 1.38 dan ancaman (threat) sebesar 1.62. Hasil perhitungan ini mengarahkan matrik berada pada kuadran III dimana kedua nilai yang dihasilkan nilainya negatif. Nilai bobot dan rating dari Weakness dan Threat atau (W-T) menunjukan urgensi penanganan dan tingkat kepentingan yang tinggi. Matrik SWOT di sajikan pada Gambar 2.

\section{Alternatif Strategi Pengembangan}

Berdasarkan hasil perhitungan analisis SWOT, strategi yang sesuai untuk diterapkan di Desa Kaliwlingi adalah strategi S-O atau Strength - Opportunity. Strategi S-O merupakan strategi yang menggunakan kekuatan untuk menyingkapi berbagai peluang yang ada. Hasil ini sesuai dengan peringkat I, II, III, IV secara berturut-turut yaitu Strategi S-O (3.88), strategi W-O (3.29), strategi S-T (2.80) dan strategi W-T (2.21). Strategi S-O yang dapat dilakukan antara lain :(1) Peningkatan partisipasi masyarakat dan peran pemerintah maupun non pemerintah dalam upaya perlindungan dan rehabilitasi mangrove. (2) Perbaikan infrastruktur dan pengembangan teknologi untuk menunjang kawasan ekowisata mangrove. (3) Pengelolaan potensi laut maupun produk mangrove secara konservatif. Pengembangan produk olahan laut maupun olahan dari mangrove di Desa Kaliwlingi juga sudah cukup baik dan konservatif. Pengelolaan potensi laut dan produk mangrove di Desa Kaliwlingi ini dinilai konservatif karena masih mengutamakan kelestarian sumberdaya alam ekosistem mangrove. Produk olahan laut yang sudah mulai dilakukan diantaranya seperti bandeng cabut duri dan budidaya kepiting soka.

Berdasarkan hasil perhitungan SWOT, Strategi yang sesuai untuk diterapkan di Desa Sawojajar adalah strategi W-T atau Weakness-Threat. Strategi W-T merupakan strategi untuk mengurangi dan menyingkapi kelemahan dengan cara melihat dari segi ancaman yang akan timbul. Hasil ini sesuai dengan peringkat I, II, III, IV secara berturut-turut yaitu Strategi W-T (3.86), 
strategi W-O (3.62), strategi S-T (2.61) dan strategi S-O (2.37). Strategi W-T yang dapat dilakukan antara lain : (1) Pengembangan ide dalam upaya memperbaiki dan mengembangkan infrastruktur di ekowisata mangrove. Desa Sawojajar memiliki potensi yang cukup besar dengan adanya sumberdaya ekosistem hutan mangrove yang masih alami sehingga dapat dipergunakan untuk dijadikan tempat ekowisata. Ekowisata di Desa Sawojajar dibangun sekitar tahun 2015 dan masih tergolong baru, namun dengan adanya ekowisata yang dibangun cukup menunjang perekonomian desa. (2) Pembinaan masyarakat untuk upaya inovasi produk yang dihasilkan dari laut maupun mangrove. (3) Pembinaan masyarakat secara aktif untuk ikut serta monitoring dan evaluasi kegiatan rehabilitasi ekosistem mangrove. Peran masyarakat dalam kegiatan monitoring dan evaluasi rehabilitasi mangrove di Desa Sawojajar masih rendah, hal ini dapat dilihat dari terbatasnya informasi mengenai tingkat keberhasilan program rehabilitasi dan presentase survival

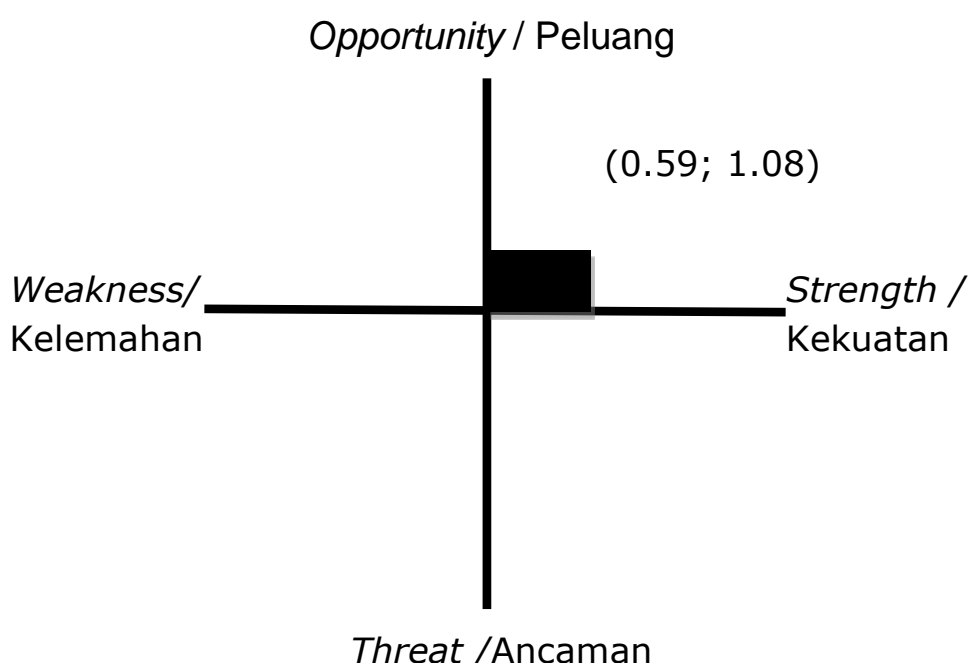

Gambar 1. Matrik SWOT di Desa Sawojajar, Kabupaten Brebes, Jawa Tengah

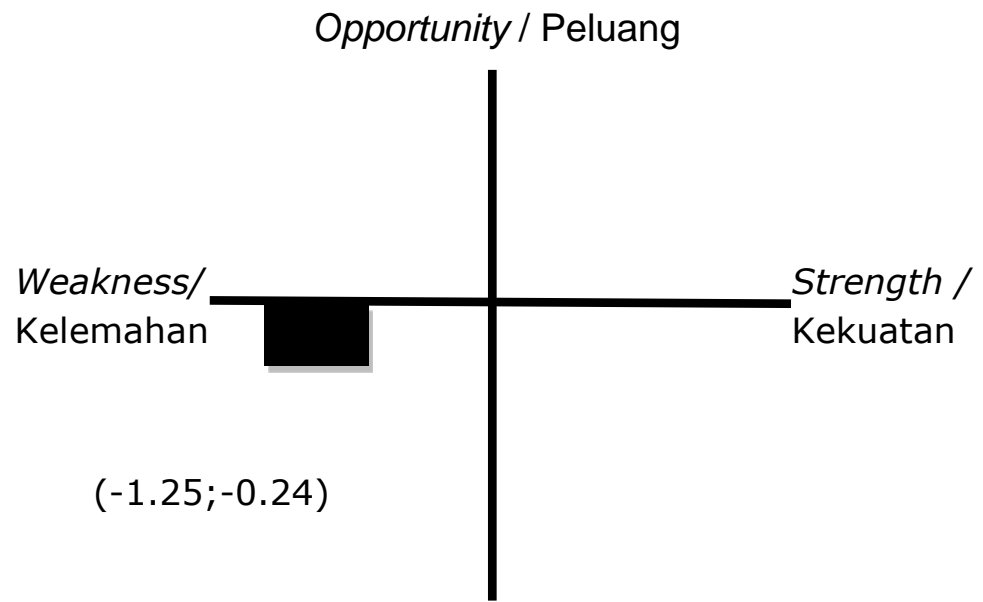

Threat /Ancaman

Gambar 2. Matrik SWOT di Desa Sawojajar, Kabupaten Brebes, Jawa Tengah

rate atau kelulushidupan tanaman mangrove di Desa Sawojajar. (4) Penanggulangan sampah yang berada di kawasan ekosistem hutan mangrove. Sampah yang berada di kawasan ekosistem hutan mangrove biasanya banyak berupa sampah rumah tangga yang berasal dari laut, sungai maupun daratan. Sampah yang menumpuk akan berdampak buruk pada kestabilan ekosistem dan bagi rehabilitasi mangrove. 


\section{KESIMPULAN}

Nilai total ekonomi) ekosistem hutan mangrove di Desa Kaliwlingi adalah sebesar Rp 12.912.098.100/tahun. Desa Sawojajar memiliki nilai total ekonomi sebesar Rp 5.519.784.145/tahun. Strategi pengembangan ekosistem mangrove di Desa Kaliwlingi adalah peningkatan partisipasi masyarakat dan peran pemerintah dalam upaya perlindungan dan rehabilitasi mangrove, perbaikan infrastuktur dan pengembangan teknologi untuk menunjang kawasan ekowisata mangrove serta pengelolaan potensi laut maupun produk mangrove secara konservatif. Strategi pengembangan ekosistem mangrove di Desa Sawoajajar adalah pengembangan ide untuk memperbaiki dan mengembangkan ekowisata mangrove seperti perbaikan infrastruktur akses jalan menuju ekowisata, pembinaan masyarakat untuk upaya inovasi produk laut atau produk mangrove seperti pembuatan jajanan mangrove, pembinaan masyarakat secara aktif untuk ikut serta memonitoring dan mengevaluasi kegiatan rehabilitasi mangrove dan penanggulangan sampah yang berada di kawasan ekosistem mangrove seperti pengaplikasian mangrove bin.

\section{DAFTAR PUSTAKA}

Ariftia, R.I., Quarniati, R., \& Herwanti. 2014. Nilai Ekonomi Total Hutan Mangrove Desa Margasari Kecamatan Labuhan Maringgai Kabupaten Lampung Timur. Universitas Lampung. Lampung Arikunto, S. 2010. Prosedur Penelitian Suatu Pendekatan Praktek. Rineka Cipta. Jakarta

Bann, C. 1998. The Economic Valuation of Mangroves: A Manual for Researchers. EEPSEA. London

Kordi, K.M.G.H. \& Ghufran, M., 2012. Ekosistem Mangrove Potensi, Fungsi dan Pengelolaan.

Rineka Cipta. Jakarta.

Prasetiyo, D.E., Zulfikar, F., Shinta, \& Zulkarnain, I. 2015. Valuasi Ekonomi Hutan Mangrove di Pulau Untung Jawa Kepulauan Seribu : Studi Konservasi Berbasis Green Economy. Surya University. Jakarta

Putra, F.P. 2016. Valuasi Ekonomi Sumberdaya Hutan Mangrove Di Desa Lateri, Kecamatan Baguala, Kota Ambon. Institut Sepuluh November. Surabaya

Riyastini, I.A.P. 2015. Valuasi Ekonomi Mangrove Desa Pejarakan, Kecamatan Gerokgak, Kabupaten Buleleng. Dinas Kelautan Dan Perikanan. Bali

Ruitenbeek, H.J. 1992. Mangrove mana-gement: an economic analysis of management options with a focus on Bintuni Bay, Irian Jaya. Jakarta and Halifax; Environmental Management Development in Indonesia Project. 51p.

Suyono, S., Boedi, H., \& Ocky, K.R. 2015. Pemetaan Degradasi Ekosistem Mangrove dan Abrasi Pantai Berbasis Geographic Information System di Kabupaten Brebes-Jawa Tengah. Fakultas Perikanan dan Ilmu Kelautan. Universitas Diponegoro. Semarang

Suzana, B.O.L., Timbang, J., Kaunag, R., \& Ahmad, F. 2011. Valuasi ekonomi sumberdaya hutan mangrove di Desa Palaes Kecamatan Likupang Barat Kabupaten Minahasa Utara. AgriSosioekonomi, 7(2):29-38.

Usman, H. \& Purnomo, A. 2008. Metodologi Penelitian Sosial. Bumi Aksara. Jakarta. 